\title{
Korelasi Jumlah Cluster of Differentiation 4 dengan Jenis Bakteri Penyebab Infeksi Paru dari Kultur Bilasan Bronkoalveolar pada Pasien Human Immunodeficiency Virus
}

\author{
Melindah, ${ }^{1}$ Prayudi Santoso, ${ }^{2}$ Uun Sumardi, ${ }^{2}$ Yana Akhmad Supriatna, ${ }^{2}$ Dewi Kartika Turbawati ${ }^{2}$ \\ ${ }^{1}$ Rumah Sakit Umum Daerah Majalengka, ${ }^{2}$ Departemen/SMF Ilmu Penyakit Dalam Fakultas Kedokteran \\ Universitas Padjadjaran/Rumah Sakit Dr. Hasan Sadikin Bandung
}

\begin{abstract}
Abstrak
Infeksi paru bakteri adalah penyebab utama morbiditas dan mortalitas pasien human immunodeficiency virus (HIV)/acquired immunodeficiency syndrome (AIDS). Infeksi HIV menyebabkan disfungsi sistem kekebalan yang dimanifestasikan penurunan jumlah cluster of differentiation 4 (CD4). Tujuan penelitian menentukan hubungan jumlah CD4 dengan jenis bakteri penyebab infeksi paru dari kultur bilasan bronkoalveolar pasien HIV di RSDr. Hasan Sadikin Bandung. Penelitian analitik observasional dengan rancangan potong lintang. Pengambilan sampel sejak November 2011 sampai Oktober 2013 di Departemen Ilmu Penyakit Dalam RS Dr. Hasan Sadikin Bandung. Subjek 39 orang memenuhi kriteria inklusi, didapatkan usia rata-rata 32 tahun. Jumlah median CD4 18 (rentang, 0-190) $\mathrm{sel} / \mathrm{mm}^{3}$. Hasil kultur jenis bakteri batang gram negatif 29/39 sampel dan kokus gram positif $10 / 39$ sampel. Spesies terbanyak Pseudomonas aeruginosa 11/39 sampel, Klebsiella pneumoniae 11/39 sampel dan Streptococcus viridans $10 / 39$ sampel. Analisis statistik berdasarkan point biserial correlation terdapat korelasi lemah $(\mathrm{r}=0,232)$ dan tidak bermakna antara CD4 dan jenis bakteri penyebab dengan nilai $p=0,209(p>0,05)$. Arah korelasi menunjukkan semakin kecil jumlah CD4 semakin besar kemungkinan bakteri batang gram negatif sebagai penyebab infeksi paru. Penelitian ini menunjukkan korelasi lemah antara jumlah CD4 dan jenis bakteri penyebab infeksi paru dari bilasan bronkoalveolar pada pasien infeksi HIV di RS Dr. Hasan Sadikin Bandung. [MKB. 2016;48(1):32-8]
\end{abstract}

Kata kunci: Bilasan bronkoalveolar, human immunodeficiency virus (HIV), infeksi paru bakteri, jumlah CD4

\section{Correlation between Cluster of Differentiation 4 Cell Counts and Types of Bacteria Causing Lung Infection from Cultured Washing of Bronchoalveolar Lavage in Human Immunodeficiency Virus Patients}

\begin{abstract}
Bacterial lung infection is the leading cause of morbidity and mortality of patients with human immunodeficiency virus (HIV)/acquired immunodeficiency syndrome (AIDS). HIV infection causes immune system dysfunction, which is manifested by decreased cluster of differentiation 4 (CD4) cell counts. The purpose of this study was to determine the correlation between CD4 cell counts and the type of bacteria that caused lung infection from cultured washing of bronchoalveolar lavage in HIV patients in Dr. Hasan Sadikin Hospital Bandung. This was an observational analytic study with a cross-sectional design. Subjects were collected from November 2011 to October 2013 in Internal Departement Dr. Hasan Sadikin Hospital Bandung. There were 39 subjects enrolled with the average age of patients was 32 years. The median CD4 cell counts was 18 (range, 0-190) cell $/ \mathrm{mm}^{3}$. The type of gram-negative rods bacteria was 29/39 samples and gram-positive cocci was 10/39 samples. Most species were Pseudomonas aeruginosa 11/39 samples, Klebsiella pneumoniae 11/39 samples and Streptococcus viridans 10/39 samples. Statistical analysis based on a point biserial correlation showed weak $(r=0.232)$ and no significant correlation between CD4 cell counts and the type of bacteria $(p>0.05)$. The weak correlation was the smaller the number of CD4 cell counts, the greater possibility of the gram-negative rod bacteria being the cause of the infection. This study concluded that there is only a weak and no correlation between the number of CD4 cell counts and the type of bacteria causing the lung infection obtained from bronchoalveolar lavage in patients with HIV in Dr. Hasan Sadikin Hospital Bandung. [MKB. 2016;48(1):32-8]
\end{abstract}

Key words: Bacterial lung infection, bronchoalveolar lavage, CD4 cell counts, human immunodeficiency virus

Korespondensi: Melindah, dr., Rumah Sakit Umum Daerah (RSUD) Majalengka Jalan Kesehatan No. 77 Majalengka Wetan, Kabupaten Majalengka, mobile 08122421977, e-mail melindah.meli@gmail.com 


\section{Pendahuluan}

Infeksi human immunodeficiency virus (HIV) saat ini menjadi pandemi global, diperkirakan 35 juta orang terinfeksi HIV pada tahun 2013. ${ }^{1}$ Kasus HIV/acquired immunodeficiency syndrome atau AIDS di Indonesia pertama kali ditemukan di Bali pada tahun 1987. ${ }^{2}$ Penyebaran HIV/AIDS di Indonesia cenderung terus meningkat dan laju epidemi HIV di Indonesia tercepat di Asia pada 5 tahun terakhir. ${ }^{3}$

Kejadian infeksi oportunistik pada HIV/AIDS menurun drastis di Amerika Serikat dan Eropa selama penggunaan terapi antiretroviral, tetapi kejadian infeksi oportunistik paru tetap menjadi penyebab utama morbiditas serta mortalitas pasien HIV/AIDS. Penderita HIV/AIDS selama perjalanan penyakitnya itu sekurang-kurangnya akan mengalami 1 (satu) episode infeksi paru. Infeksi paru terjadi sebanyak 2 kali atau lebih pada saat tahun pertama pasien infeksi HIV terdiagnosis AIDS. ${ }^{4}$

Kemampuan mikroorganisme menginfeksi paru-paru tidak hanya bergantung pada suatu patogenisitasnya, tetapi juga pada kemampuan mikroorganisme untuk mengatasi kekebalan tubuh tuan rumah. Infeksi HIV mengakibatkan penurunan kuantitatif dan juga kualitatif cluster of differentiation 4 (CD4) limfosit $\mathrm{T}^{5}$ Delapan puluh persen kasus pneumonia bakteri terjadi pada kondisi CD4 $<400 \mathrm{sel} / \mathrm{mm}^{3}$ dan pneumonia bakteri terbanyak terjadi pada CD $4<200$ sel/ $\mathrm{mm}^{3}{ }^{6}$.

Jenis bakteri gram positif yang menyebabkan infeksi paru tersering pada populasi HIV adalah Streptococcus pneumoniae (S. pneumoniae). Infeksi S. pneumoniae sekitar $20 \%$ dari semua bakteri penyebab, $40 \%$ dari pneumonia yang telah terdiagnosis dan $70 \%$ dari pneumonia bakteremia. ${ }^{7}$ Haemophilus influenzae atau $H$. influenzae adalah bakteri gram negatif yang dikaitkan dengan 10-15\% dari kasus infeksi paru, termasuk 5\% dari bakteri. Jenis bakteri gram negatif yang banyak menyebabkan infeksi pada HIV stadium lanjut adalah Pseudomonas aeruginosa (P. aeruginosa), Klebsiella pneumoniae (K. pneumoniae), dan Enterobacter sp. ${ }^{8}$

Gambaran foto toraks pada infeksi paru pasien infeksi HIV banyak kemiripan meskipun etiologi mikroorganisme penyebab berbeda sehingga akan memerlukan pemeriksaan kultur mikrobiologik definitif atau diagnosis patologi sebagai panduan terapi empirik. ${ }^{9}$ Pemeriksaan diagnostik untuk dapat menentukan penyebab mikrobiologik didapat melalui kultur dari darah dan sputum saluran pernapasan atau sampel dari tindakan invasif seperti bronkoskopi dengan bilasan bronkoalveolar. Bronkoskopi dengan bilasan bronkoalveolar sebagai alat penegakan diagnosis ditinjau sensitivitas, spesifisitas, serta risiko tindakan menurut Baughman dan Lower adalah suatu prosedur diagnostik pneumonia yang mempunyai sensitivitas baik dan spesifisitas tinggi serta risiko tindakan sedang. ${ }^{7}$

Penelitian hubungan jumlah CD4 dengan jenis bakteri penyebab infeksi paru dari kultur bilasan bronkoalveolar pasien belum pernah dilakukan sebelumnya. Berdasarkan uraian di atas, dilakukan penelitian untuk menentukan hubungan antara jumlah CD4 dan jenis bakteri penyebab infeksi pada paru dari kultur bilasan bronkoalveolar pada pasien HIV di Rumah Sakit Dr. Hasan Sadikin (RSHS) Bandung.

\section{Metode}

Penelitian ini merupakan bagian dari penelitian Etiologi Penyebab Infeksi Paru pada Pasien HIV di RSHS Bandung oleh Prayudi S. Subjek adalah semua pasien dengan gejala infeksi paru baru dan infeksi HIV yang sedang dirawat di ruangan rawat inap, Instalasi Gawat Darurat (IGD), dan pasien rawat jalan di Poliklinik Teratai RSHS yang memenuhi kriteria inklusi dan bersedia mengikuti penelitian dengan mengisi lembar persetujuan (informed consent). Kriteria inklusi adalah pasien infeksi HIV dengan gejala infeksi paru kasus baru secara klinis dan foto toraks dan berusia di atas 14 tahun. Kriteria eksklusi adalah pasien gagal napas dan dalam pengobatan antibiotik.

Penelitian ini adalah penelitian observasional analitik dengan rancangan potong lintang yang mengukur hubungan variabel bebas (jumlah CD4) dengan variabel terikat (hasil jenis kultur bakteri). Sampel tersebut dipilih berdasarkan urutan kedatangan pasien selama periode bulan November 2011-Oktober 2013. Ukuran sampel penelitian dapat dihitung berdasarkan rumus ukuran sampel untuk analitik korelasi ${ }^{10}$ dengan taraf kemaknaan $5 \%\left(\mathrm{Z}_{\alpha}=1,96\right)$ dan power test $80 \%\left(Z_{\beta}=0,84\right)$, besarnya koefisen korelasi yang ditetapkan $r=0,5$, diperoleh subjek penelitian minimal 33 orang.

Analisis statistik uji normalitas data numerik dilakukan uji Shapiro-Wilk. Hipotesis itu diuji memakai parameter point biserial correlation untuk menentukan kemaknaan dan menilai $r$ untuk mengetahui besarnya korelasi. Hasil uji bermakna apabila nilai $\mathrm{p}<0,05$. 


\section{Hasil}

Sumber data penelitian ini mempergunakan dua sumber data, data sekunder yang didapat dari penelitian sebelumnya dengan judul "Etiologi Penyebab Infeksi Paru pada Pasien HIV di RSHS Bandung tahun 2011" sebanyak 24 subjek. Data primer didapatkan sebanyak 15 subjek diambil selama periode penelitian, kemudian dilakukan analisis data. Pada setiap subjek penelitian itu diambil sampel bilasan bronkoalveolar melalui bronkoskopi dan dilakukan pemeriksaan kultur serta uji kepekaan bakteri.

Karakteristik subjek penelitian dapat dilihat pada Tabel 1. Subjek penelitian sebanyak 39 orang terdiri atas 22 orang laki-laki dan 17 orang perempuan. Usia rata-rata 32 tahun. Jumlah CD4 didapatkan median $18 \mathrm{sel} / \mathrm{mm}^{3}$ dengan rentang 0 sampai $190 \mathrm{sel} / \mathrm{mm}^{3}$. Total lymphocyte count (TLC) didapatkan median $592 \mathrm{sel} / \mathrm{mm}^{3}$ dengan rentang 95 sampai $2.304 \mathrm{sel} / \mathrm{mm}^{3}$. Jumlah absolute neutrophil count (ANC) 3.264 $\mathrm{sel} / \mathrm{mm}^{3}$ dengan rentang 558 sampai 17.730 $\mathrm{sel} / \mathrm{mm}^{3}$. Median nilai neutrophil lymphocyte count ratio (NLCR) 5,5 dengan rentang 0,9 sampai 96. Penularan melalui penasun 14 orang,

Tabel 1 Karakteristik Subjek Penelitian

\begin{tabular}{|c|c|c|}
\hline Karakteristik & $n=39$ & Nilai p \\
\hline \multicolumn{3}{|l|}{ Jenis kelamin } \\
\hline Laki-laki & 22 & $\left.0,231^{*}\right)$ \\
\hline Perempuan & 17 & \\
\hline \multicolumn{3}{|l|}{ Usia (tahun) } \\
\hline Rata-rata $\pm S B$ & $32,1 \pm 5,1$ & \\
\hline \multicolumn{3}{|l|}{ CD4 } \\
\hline Median $\left(\mathrm{sel} / \mathrm{mm}^{3}\right)$ & $18(0-190)$ & \\
\hline \multicolumn{3}{|l|}{ TLC } \\
\hline Median $\left(\mathrm{sel} / \mathrm{mm}^{3}\right)$ & $592(95-2,304)$ & \\
\hline \multicolumn{3}{|l|}{ ANC } \\
\hline Median $\left(\mathrm{sel} / \mathrm{mm}^{3}\right)$ & $3.264(558-7.730)$ & \\
\hline \multicolumn{3}{|l|}{ NLCR } \\
\hline Median & $5,5(0,9-96)$ & \\
\hline \multicolumn{3}{|l|}{ Penularan } \\
\hline Penasun & 14 & \\
\hline Heteroseksual & 24 & \\
\hline Homoseksual & 1 & \\
\hline
\end{tabular}

Keterangan: *) Uji-t

CD4: cluster of differentiation 4

TLC: total lyimphocyte count

ANC: absolute neutrophil count

NLCR: neutrophil lymphocyte count ratio
Tabel 2 Hasil Kultur Jenis Bakteri Penyebab Infeksi Paru dari Bilasan Bronkoalveolar pada Pasien HIV

\begin{tabular}{lcc}
\hline \multicolumn{1}{c}{ Bakteri Penyebab } & $\begin{array}{c}\text { Batang } \\
\text { Gram } \\
\text { Negatif }\end{array}$ & $\begin{array}{c}\text { Kokus } \\
\text { Gram } \\
\text { Positif }\end{array}$ \\
\hline P. aeruginosa & 11 & \\
$\begin{array}{l}\text { Klebsiella pnemoniae } \\
\text { S. viridans }\end{array}$ & 11 & 10 \\
Enterobacter cloacae & 2 & \\
$\begin{array}{l}\text { Pseudomonas putida } \\
\text { Pseudomonas }\end{array}$ & 2 & \\
fluorescens & 1 & \\
$\begin{array}{l}\text { Escherichia coli } \\
\text { Stenotrophomonas }\end{array}$ & 1 & \\
maltophilia & 1 & \\
& 19 & \\
\hline
\end{tabular}

heteroseksual 24 orang, dan juga homoseksual seorang.

Hasil jenis bakteri hasil kultur dari bilasan bronkoalveolar didapatkan bakteri batang gram negatif sebesar 19 dari 29 (terbanyak adalah $P$. aeruginosa dan $K$. pneumoniae) dan bakteri kokus gram positif sebesar 10 dari 29 adalah bakteri Streptococcus viridans (S. viridans) dapat dilihat pada Tabel 2.

Hubungan jumlah CD4 dengan jenis bakteri penyebab infeksi paru dapat dilihat pada Tabel 3. Jenis bakteri batang gram negatif dengan median jumlah CD4 sebesar $15 \mathrm{sel} / \mathrm{mm}^{3}$ dengan rentang antara 3 sampai $157 \mathrm{sel} / \mathrm{mm}^{3}$. Bakteri kokus gram positif didapatkan median jumlah CD4 lebih besar, yaitu $28,5 \mathrm{sel} / \mathrm{mm}^{3}$ dengan rentang antara 0 sampai $190 \mathrm{sel} / \mathrm{mm}^{3}$. Hasil analisis stastistik dengan point biserial correlation menunjukkan korelasi lemah $(r=0,207)$ dan tidak bermakna antara jumlah CD4 dan jenis bakteri penyebab infeksi paru dengan $p=0,103(p>0,05)$. Arah korelasi positif yang artinya semakin kecil nilai CD4 semakin besar kemungkinan bakteri batang gram negatif sebagai penyebab infeksi.

Tabel 4 memperlihatkan hubungan antara jenis bakteri penyebab infeksi paru dan TLC. Bakteri batang gram negatif dengan median TLC lebih rendah, yaitu $420 \mathrm{sel} / \mathrm{mm}^{3}$ dengan rentang antara 95 sampai $2.304 \mathrm{sel} / \mathrm{mm}^{3}$. Bakteri kokus gram positif didapatkan median TLC, yaitu 828 $\mathrm{sel} / \mathrm{mm}^{3}$ dengan rentang antara 297 sampai $1.575 \mathrm{sel} / \mathrm{mm}^{3}$. Hasil analisis stastistik dengan point biserial correlation didapatkan korelasi 
Tabel 3 Hubungan Jumlah CD4 dengan Jenis Bakteri Penyebab Infeksi Paru Menggunakan Bilasan Bronkoalveolar pada Pasien HIV

\begin{tabular}{lccccc}
\hline \multirow{2}{*}{ Jenis Bakteri } & \multicolumn{3}{c}{ CD4 } & Koefisien \\
\cline { 2 - 6 } & $\mathbf{n}$ & Median & Rentang & (r)*asi & Nilai $\mathbf{p}^{*}$ \\
\hline Batang gram negatif & 29 & 15 & $3-157$ & 0,207 & 0,103 \\
Kokus gram positif & 10 & 28,5 & $0-190$ & & \\
\hline
\end{tabular}

Keterangan: *) berdasarkan point biserial correlation

lemah $(\mathrm{r}=0,280)$ dan bermakna antara TLC dan jenis bakteri penyebab $(\mathrm{p}=0,042)$. Arah korelasi positif yang artinya semakin kecil nilai TLC bahwa semakin besar juga kemungkinan bakteri batang gram negatif sebagai penyebab infeksi.

Uji kepekaan P. aeruginosa sensitif 100\% didapatkan terhadap amikasin dengan nilai minimum inhibitory concentration (MIC) yaitu, sebesar $\leq 2 \mu \mathrm{g} / \mathrm{mL}$, seftazidim (MIC $\leq 4 \mu \mathrm{g} / \mathrm{mL}$ ) dan piperacillin tazobactam (MIC $\leq 32 \mu \mathrm{g} / \mathrm{mL}$ ). Meropenem resistensi sebesar 22\% (MIC $\geq 8 \mu \mathrm{g}$ / $\mathrm{mL}$ ), sedangkan siprofloksasin dan levofloksasin dengan resitensi sebesar 43\% (MIC $\geq 8 \mu \mathrm{g}$ / $\mathrm{mL}$ ). Resistensi $100 \%$ didapatkan terhadap 6 antibiotik, yaitu amoksilin-klavulanat (MIC $\geq 32$ $\mu \mathrm{g} / \mathrm{mL}$ ), kefotaxim (MIC $\geq 16 \mu \mathrm{g} / \mathrm{mL}$ ), seftriakson (MIC $\geq 64 \mu \mathrm{g} / \mathrm{mL}$ ), kotrimoksazol (MIC $\geq 320 \mu \mathrm{g}$ / $\mathrm{mL}$ ), tigesiklin (MIC $\geq 8 \mu \mathrm{g} / \mathrm{mL}$ ), dan ampisilin sulbatam (MIC $\geq 32 \mu \mathrm{g} / \mathrm{mL}$ ), dapat dilihat pada Gambar 1.

Hasil uji kepekaan $K$. pneumoniae dapat dilihat pada Gambar 2. Hasil kepekaan dengan sensitif $100 \%$ didapatkan pada amikasin (MIC $\leq 2$ $\mu \mathrm{g} / \mathrm{mL}$ ), imipenem (MIC $\leq 1 \mu \mathrm{g} / \mathrm{mL}$ ), meropenem (MIC $\leq 0,25 \mu \mathrm{g} / \mathrm{mL}$ ), piperasilin tazobaktam (MIC $\leq 4 \mu \mathrm{g} / \mathrm{mL}$ ) dan tigesiklin (MIC $\leq 0,5 \mu \mathrm{g} /$ $\mathrm{mL}$ ). Resitensi siprofloksasin sebesar 22\% (MIC $\geq 4 \mu \mathrm{g} / \mathrm{mL}$ ) dan resistensi levofloksasin sebesar $12 \%$ (MIC $\geq 8 \mu \mathrm{g} / \mathrm{mL}$ ). Resistensi sebesar $25 \%$ terhadap antibiotik sefalosporin generasi yang ketiga (MIC $\geq 64 \mu \mathrm{g} / \mathrm{mL}$ ), sedangkan ampisilin sulbaktam resisten sebesar $100 \%$ (MIC $\geq 32$ $\mu \mathrm{g} / \mathrm{mL}$ ). Penelitian ini didapatkan 33\% bakteri
K. pneumoniae adalah extended spectrum beta lactamases (ESBL).

\section{Pembahasan}

Pada penelitian ini didapatkan distribusi jenis kelamin laki-laki tidak berbeda bermakna bila dibandingkan dengan perempuan. Keadaan ini sesuai dengan laporan perkembangan HIV/AIDS Kementerian Kesehatan Republik Indonesia 2012 yang menyatakan rasio penderita HIV lakilaki dan perempuan adalah 1 banding $1 .^{11}$

Laporan perkembangan penyakit HIV/AIDS di Indonesia mencatat sumber penularan HIV pada tahun 2012 paling banyak adalah heteroseksual $(58,7 \%)$, penasun $(17,9 \%)$, diikuti penularan perinatal $(2,7 \%)$ dan juga kelompok transgender $(2,3 \%) \cdot{ }^{11}$ Hal ini sesuai dengan hasil penelitian ini didapatkan penularan pasien HIV/AIDS pada penelitian ini terbanyak melalui heteroseksual $(61,5 \%)$, penasun sebanyak $35,9 \%$, dan juga homoseksual $(2,6 \%){ }^{11}$

Median jumlah CD4 subjek penelitian adalah $18 \mathrm{sel} / \mathrm{mm}^{3}$ dengan rentang $0-190 \mathrm{sel} / \mathrm{mm}^{3}$. Hasil median CD4 yang rendah pada penelitian ini sesuai dengan penelitian Wisaksana dkk. ${ }^{12}$ mengenai pasien HIV di Jawa Barat yang datang berobat didapatkan dengan jumlah CD4 yang rendah.

Jenis bakteri batang gram negatif didapatkan median jumlah CD4 $15 \mathrm{sel} / \mathrm{mm}^{3}$ lebih kecil dibanding dengan median jumlah CD 4 pada kokus

Tabel 4 Hubungan TLC dengan Jenis Bakteri Penyebab Infeksi Paru Menggunakan Bilasan Bronkoalveolar pada Pasien HIV

\begin{tabular}{|c|c|c|c|c|c|}
\hline \multirow{2}{*}{ Jenis Bakteri } & \multicolumn{3}{|c|}{ TLC } & \multirow{2}{*}{$\begin{array}{c}\text { Koefisien } \\
\text { Korelasi (r)* }\end{array}$} & \multirow{2}{*}{ Nilai $\mathbf{p}^{*}$} \\
\hline & $\mathbf{N}$ & Median & Rentang & & \\
\hline Batang gram negatif & 29 & 420 & $95-2.304$ & 0,280 & 0,042 \\
\hline Kokus gram positif & 10 & 828 & $297-1.575$ & & \\
\hline
\end{tabular}

Keterangan: *)berdasarkan point biserial correlation 
- Pseudomonas aeruginosa

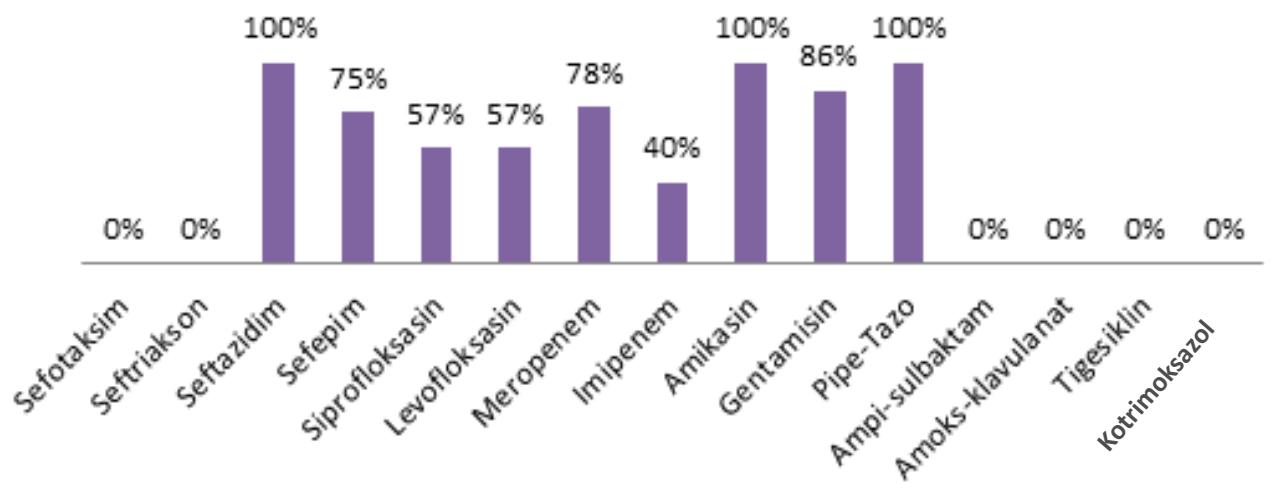

\section{Gambar 1 Diagram Hasil Uji Kepekaan Bakteri P. aeruginosa}

gram positif sebesar $28,5 \mathrm{sel} / \mathrm{mm}^{3}$, walaupun ada kecenderungan jumlah CD4 yang lebih rendah pada bakteri batang gram negatif, tetapi analisis stastistik menunjukkan terdapat korelasi lemah dan tidak bermakna antara jumlah CD4 dan jenis bakteri. Median jumlah CD4 yang sangat rendah $\left(<50 \mathrm{sel} / \mathrm{mm}^{3}\right)$ seperti pada penelitian ini menunjukkan telah terjadi disfungsi kekebalan tahap lanjut. Disfungsi kekebalan tahap lanjut pada kedua kelompok jenis bakteri dapat menjadi penyebab serta korelasi lemah dan tidak bermakna antara median jumlah CD4 dan jenis bakteri penyebab infeksi paru pasien HIV pada penelitian ini. Hal lain yang menjelaskan hasil penelitian ini kemungkinan disebabkan penurunan progresif CD4 limfosit T pada pasien HIV menurut konsep saat ini adalah konsekuensi dari aktivasi kekebalan kronik. Aktivasi CD4 limfosit T secara terus menerus sebagai respons terhadap virus HIV merupakan target imun yang akhirnya menyebabkan ketidakseimbangan dan deplesi CD4 limfosit T sistemik. ${ }^{13}$

Median TLC pada jenis bakteri batang gram negatif berkorelasi lemah dan bermakna dibanding dengan median TLC bakteri kokus gram positif. Semakin kecil nilai TLC semakin besar kemungkinan bakteri batang gram negatif sebagai penyebab infeksi. Hal ini dapat dijelaskan dari nilai TLC yang menunjukkan jumlah limfosit secara keseluruhan terhadap proses kekebalan suatu infeksi paru bakteri. Beberapa penelitian memperlihatkan hipotesis penurunan jumlah limfosit sistemik disebabkan oleh perpindahan limfosit ke paru-paru sebagai pertahanan seluler paru. Penelitian ini didapatkan infeksi bakteri batang gram negatif terjadi penurunan TLC yang lebih banyak dibanding dengan bakteri kokus gram positif. Hal ini mungkin dapat dijelaskan karena limfositopenia tersebut disebabkan oleh apoptosis akibat endotoksin yang dihasilkan

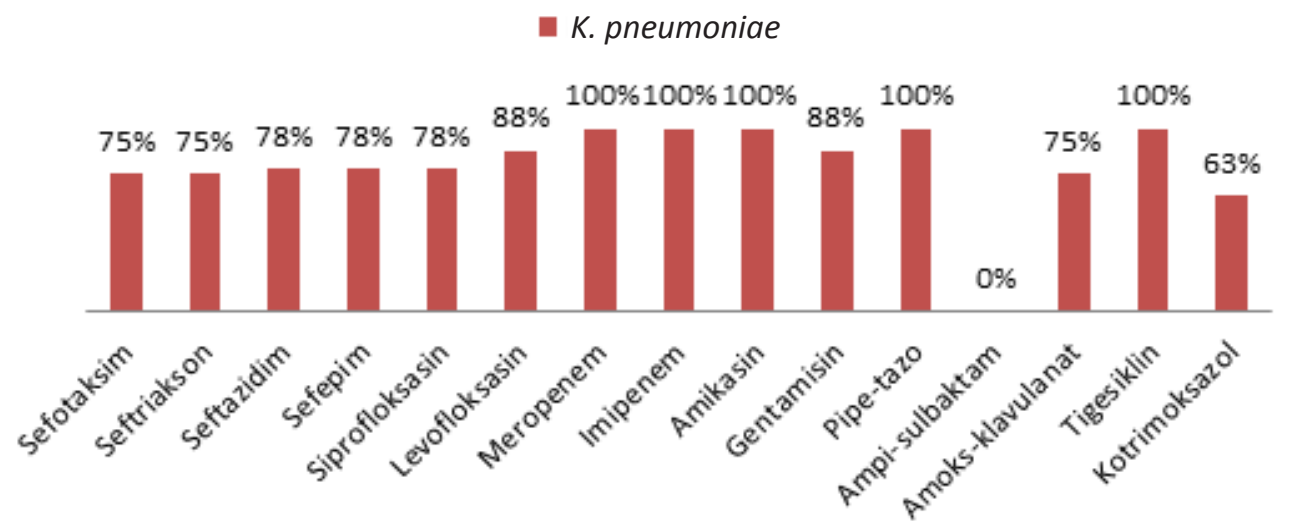

Gambar 2 Diagram Hasil Uji Kepekaan Bakteri K. pneumoniae 
lipopolisakarida pada dinding sel bakteri gram negatif menyebabkan proses inflamasi yang jauh lebih hebat dan sering menyebabkan sepsis. ${ }^{14}$

Bakteri paling banyak penyebab dari infeksi paru pada penelitian ini adalah $P$. aeruginosa (11/39), K. pneumoniae (11/39), dan S. viridans $(10 / 39)$. Hal ini berbeda dengan hasil penelitian sebelumnya dilakukan di negara Amerika dan Eropa yang menyatakan bakteri penyebab infeksi paru paling sering pada populasi HIV adalah $S$. pneumoniae dan $H$. influenzae. ${ }^{7}$ Penelitian lain yang berbeda dengan hasil penelitian ini adalah penelitian Fangman dan Sax ${ }^{9}$ menyatakan bahwa bakteri sebagai penyebab paling sering pneumonia komunitas pada populasi umum di Asia Tenggara adalah S. pneumoniae (17\%), Chlamydia pneumoniae (14,3\%), K. pneumoniae $(6,1 \%)$, dan Mycoplasma pneumoniae $(4,1 \%)$. Perbedaan hasil ini dapat dijelaskan oleh karena keputusan diagnostik infeksi paru bergantung pada wilayah geografis dan prevalensinya di populasi umum.

Dua penelitian yang dilakukan di Indonesia menunjukkan kemiripan hasil kultur bakteri pada penelitian ini. Penelitian di Makasar dilakukan pada populasi umum didapatkan bahwa bakteri tersering penyebab infeksi paru berdasarkan kultur dari spesimen bilasan bronkus adalah $P$. aeruginosa dan $K$. pneumoniae. ${ }^{15}$ Penelitian bakteri paling banyak yang didapatkan dari pemeriksaan kultur spesimen sputum pada pasien di instalasi rawat inap RSHS Bandung, periode Januari-Juni 2012 adalah K. pneumoniae diikuti S. viridans, Acinetobacter baumannii, dan P. aeruginosa. ${ }^{16}$

Faktor lain selain masalah geografis yang menyebabkan $S$. pneumoniae tidak didapatkan pada penelitian ini oleh karena $S$. pneumoniae mikroorganisme yang sulit dikultur dikarenakan membutuhkan kebutuhan gizi dan lingkungan yang baik untuk tumbuh. Keragaman genetik organisme ini dan juga sifat $S$. pneumoniae yang eksklusif sebagai patogen manusia, sulit untuk membedakan kultur bakteri ini apabila dibanding dengan kultur strain yang berbeda bahkan dalam serotipe yang sama. Kriteria minimum untuk identifikasi serta membedakan $S$. pneumoniae dari streptokokus lain memakai tes sensitivitas empedu atau sensitivitas optochin, pewarnaan gram positif, dan aktivitas hemolitik. ${ }^{17}$ Penelitian dilaksanakan di Bagian Ilmu Kesehatan Anak dan Bagian Mikrobiologi FK Universitas Udayana/ Rumah Sakit Umum Pusat (RSUP) Sanglah Denpasar mempergunakan pemeriksaan PCR terhadap S. pneumoniae pada 106 subjek balita dengan kasus meningitis, sepsis, dan pneumonia berat didapatkan hasil tidak terdeteksinya $S$. pneumoniae. Berbeda dengan hasil penelitian sebelumnya di Surabaya 2,2/100.000 dan juga di Bandung 1/100.000 didapatkan galur $S$. pneumoniae dalam jumlah yang kecil sekali.

Penelitian ini didapatkan bahwa P. aeruginosa sensitif terhadap amikasin $100 \%$, sefalosporin antipseudomonal dan piperasilin tazobaktam, sedangkan terhadap meropenem sebanyak $22 \%$ bakteri P. aeruginosa mengalami resisten. Hal ini kemungkinan adalah konsekuensi pemakaian karbapenem yang mulai sering dipergunakan terutama untuk bakteri ESBL. ${ }^{19}$

Penelitian ini juga memperlihatkan semua bakteri P. aeruginosa penyebab infeksi paru pada pasien HIV/AIDS di RSHS resisten $100 \%$ terhadap amoksilin-klavulanat, sefalosporin generasi ketiga, kotrimoksazol, tigesiklin, dan ampisilin sulbaktam. Hasil penelitian ini juga menunjang konsensus Infectious Diseases Society of America/ American Thoracic Society untuk terapi infeksi bakteri Pseudomonas mempergunakan b-lactam antipseudomonal. ${ }^{19}$

Penelitian ini didapatkan 33\% bakteri $K$. pneumoniae adalah ESBL. Bakteri ESBL adalah bakteri yang resisten terhadap sebagian besar sefalosporin, golongan betalaktam, dan inhibitor betalaktamase. Bakteri ESBL jumlahnya saat ini meningkat oleh karena penggunaan golongan sefalosporin yang luas di seluruh dunia.

Penelitian ini juga mempunyai kelemahan, yaitu subjek penelitian ini didapatkan pasien infeksi HIV dengan jumlah CD yang rendah (median 18 dengan rentang $0-190 \mathrm{sel} / \mathrm{mm}^{3}$ ) sehingga tidak dapat diketahui bakteri penyebab infeksi paru pada jumlah CD4 yang lebih tinggi. Simpulan, didapatkan korelasi yang lemah dan tidak bermakna antara jumlah CD4 dan jenis bakteri penyebab infeksi paru dari bilasan bronkoalveolar terhadap pasien infeksi HIV di Rumah Sakit Dr. Hasan Sadikin Bandung. Hasil penelitian ini dapat dijadikan acuan pedoman terapi empirik infeksi paru bakteri pada pasien HIV dengan $\mathrm{CD}<200 \mathrm{sel} / \mathrm{mm}^{3}$.

\section{Daftar Pustaka}

1. Pusat Data Informasi Kementrian Kesehatan RI. Situasi dan analisis HIV AIDS. Jakarta: Kementrian Kesehatan RI; 2014.

2. Djajakusumah TS. Epidemiologi infeksi HIV-AIDS di Jawa Barat. Dalam: Sumantri R, Wisaksana R, Hartantri Y, penyunting. Dukungan, perawatan dan pengobatan komprehensif HIV/AIDS. Bandung: Pusat 
Informasi Ilmiah Departemen Ilmu Penyakit Dalam FK Unpad RS Dr. Hasan Sadikin; 2010. hlm. 1-9.

3. Wisaksana R. Monitoring and treatment of HIV among injecting drug users in Indonesia [Doctoral thesis]. Bandung: Pusat informasi ilmiah: Faculty of Medicine, Universitas Padjadjaran/Dr. Hasan Sadikin General Hospital; 2012.

4. Benito N, Moreno A, Miro JM, Torres A. Pulmonary infections in HIV-infected patients: an update in the $21^{\text {st }}$ century. Eur Respir J. 2012;39(3):730-45.

5. Jambo KC, Sepako E, Fullerton DG, Mzinza D, Glennie S, Wright AK, dkk. Bronchoalveolar CD4+ T cell responses to respiratory antigens are impaired in HIV-infected adults. Thorax. 2011;66:375-82.

6. Masur H. Management of opportunistic infections associated with human immunodeficiency virus infection. Dalam: Mandell GL, Bennett JE, Dolin R, penyunting. Mandell, Douglas, and Bennett's principles and practice of infectious diseases Edisi ke7. Philadelphia: Churchill Livingstone; 2010. hlm. 1855-85.

7. Benito N, Camacho AM. Pulmonary infections in HIV patients in the highly active antiretroviral therapy era. Dalam: Agusti C, Torres A, penyunting. Pulmonary infection in the immunocompromised patient. Edisi ke-1. Barcelona: Wiley-Blackwell; 2009. hlm. 117-41.

8. Çiledağ A, Karnak D. AIDS and opportunistic infections. Dalam: Zajac V, penyunting. AIDS and opportunistic infections, microbes, viruses and parasites in AIDS process. Turkey: Ankara University School of Medicine, Chest Disease Department, Cebeci-Ankara; 2011. hlm. 87-112.

9. Fangman JW, Sax PE. Human immunodeficency virus and pulmonary infection. Dalam: Fishman AP, Elias JA, Fishman JA, Senior RM, Pack AI, penyunting. Fishman's pulmonary diseases and disorders. Edisi ke-4. New York: Mc Graw Hill; 2008. hlm. 2241-64.

10. Brown JD. Point-biserial correlation coeficients. JLT Testing \& Evolution SIG Newsletter. 2001;5(3):13-7.
11. Direktorat Jenderal Pengendalian Penyakit dan Penyehatan Lingkungan. Laporan perkembangan HIV-AIDS Triwulan IV tahun 2012 Jakarta Pusat, RI KK;18 Februari 2013.

12. Wisaksana R, Crevel Rv, Kesumah N, Sudjana P, Sumantri R. Challenges in delivering HIVcare in Indonesia; experience from a referral hospital. Acta Medica Indonesia. 2009;41(1): 45-51.

13. Patel N, Koziel H. Lung immune defence in the immunocompromised patient. Dalam: Agusti C, Torres A, penyunting. Pulmonary infection in the immunocompromised patient. Edisi ke-1. Barcelona: Wiley-Blackwell; 2009. hlm. 1-19.

14. Giamarellos-Bourboulis EJ, Tsaganos T, Spyridaki E, Mouktaroudi M, Plachouras D, Vaki I, dkk. Early changes of CD4-positive lymphocytes and NK cells in patients with severe Gram-negative sepsis. Crit Care. 2006; 10(R166):1-7.

15. Rostina, Rusli B, Arief M, Hardjoeno. Pola kuman berdasarkan spesimen dan sensitivitas terhadap antimikroba. Indonesian J Clin Pathol Med Lab. 2006; 13(1):13-6.

16. Parwati I, Turbawati DK, Sugianli AK. Peta bakteri dan kepekaannya terhadap berbagai antibiotika di Rumah Sakit Umum Pusat Dr. Hasan Sadikin Bandung Tahun 2011-2012. Bandung: SMF/Departemen Patologi Klinik RSUP Dr. Hasan Sadikin Bandung; 2013.

17. Restrepo AV, Salazar BE, Agudelo M, Rodriguez CA, Zuluaga AF, Vesga 0. Optimization of culture conditions to obtain maximal growth of penicillin-resistant Streptococcus pneumoniae. BMC Microbiol. 2005;5(34):1-8.

18. Purniti PS, Subanada IB, Kari IK, Arhana B, Iswari IS, Tarini NMA. Surveilan pneumokokus dan dampak pneumonia pada anak balita. Sari Pediatri. 2011;12(5):35964.

19. Mandell LA, Wunderink RG, Anzueto A, Bartlett JG, Campbell GD, Dean NC, dkk. Infectious Diseases Society of America/ American Thoracic Society consensus guidelines on the management of Community-Acquired Pneumonia in adults. Clin Infect Dis. 2007;44:S27-72. 